\title{
Maternal and Child Health in Northern Cyprus
}

\author{
Dilek SARPKAYA GÜDER ${ }^{1 *}$
}

Sarpkaya Güder, D. (2021). Maternal and Child Health in Northern Cyprus. Journal of Health Systems and Policies (JHESP), 3,75-84.

\section{ABSTRACT}

The data insufficiency in maternal and child health criteria may lead to deficiencies in the planning of primary healthcare services. The review aimed to provide information on the general health status of Northern Cyprus with scientific studies conducted in the country along with maternal and child health indicators presented at national level. This review research uses description and documentary analysis methods. In this study, the data was collected from publications using data collection techniques. Many health indicators have been defined by the world health organization (WHO) and Turkey to evaluate maternal and child health. The data in this study was presented accordingly. It has been stated that in Northern Cyprus, the infant mortality rate is 0.8 per thousand live births, the crude birth rate is 14.6 per thousand, and the fertility rate is 1.8. No stillbirth has been reported between 2013-2017. In the studies performed, it has been found that the cesarean delivery rate was high $(47.6 \%-87.0 \%)$ and that the rate of exclusive breastfeeding in the first 6 months was very low (22.4-41.7\%). There are no sufficient data on maternal and child health indicators in the country. No primary data such as maternal 
mortality rate, infant mortality rate, mortality and stunting rate under five years of age, immunization in children, adolescent pregnancy rate, and frequency and scope of prenatal and postnatal care was available.

Keywords: Mothers, Infant, Child, Northern Cyprus, Health

\section{INTRODUCTION}

Maternal and child health is one of the most important criteria reflecting the general health status of a country and indicates the development level of society (Taşkın, 2020; Törüner and Büyükgönenç, 2012). Mothers and children have priority in healthcare services due to their different characteristics than the rest of society. These priorities are primarily given to ensure healthy mothers have healthy children and healthy children form a healthy society. The high risk of diseases and death due to biological and developmental processes and the fact that mothers and children constitute more than half of the total population, especially in developing countries, are among the other reasons for priorities (Taşkın, 2020). In the Turkish Republic of Northern Cyprus (TRNC), $47.4 \%$ of the population consists of women and $18.4 \%$ consists of children aged under 15 (KKTC Devlet Planlama Örgütü, 2017). One of the most important factors affecting the health of women and children is the educational level of women. The illiteracy rate of women in Northern Cyprus was found to be 2.7 times bigger than that of men (KKTC Devlet Planlama Örgütü, 2017).

There is no sufficient data on maternal and child health indicators in the country or it has not been specified at the national level. Some data has been reported by the Ministry of Health and the State Planning Organization and is limited only to state hospitals. However, it is known that most of the women in the country prefer private hospitals for maternal and child health services. The data insufficiency in maternal and child health criteria may lead to deficiencies in the planning of primary healthcare services. Identification of problems in this 
field is important for the development of preventive and therapeutic services. This is the first Northern Cyprus study reporting on the indicator of mother and child health. The aim of the study was to provide information on the general health status of Northern Cyprus with scientific studies conducted in the country as well as maternal and child health indicators presented at national level.

The study is a review. The research uses description and documentary analysis methods. In this review, the data was collected from publications using data collection techniques. Many health indicators have been defined by the World Health Organization (WHO) and Turkey to evaluate maternal and child health. The data in this study was presented accordingly.

Maternal and child health indicators vary worldwide. These indicators are affected by the socioeconomic factors of countries and change from one country to another (Young and Urquia, 2013). The last action of the WHO to immediately reach the health goals determined over the years, improve the world health, and end inequalities is the 'Millennium Declaration'. The goals in this declaration have been defined as the new millennium development goals. Improving maternal health and reducing child mortality are stated as the most important goals of all (Törüner and Büyükgönenç, 2012; WHO, 2012). The WHO has defined 11 health indicators to evaluate maternal and child health. These include maternal mortality ratio, newborn mortality rate, under-five child mortality, children under five who are stunted, unsatisfying demand for family planning, antenatal care coverage (at least four times during pregnancy), antiretroviral prophylaxis among pregnant women eligible for antiretroviral therapy and HIV-positive women to prevent HIV transmission, skilled birth attendants, postnatal care for mothers and babies within two days of birth, exclusive breastfeeding in the first 6 months, three doses of combined diphtheria-tetanus-pertussis immunization coverage, and antibiotic treatment for potential pneumonia (WHO, 2012). In scope of the millennium development goals in Turkey, the maternal and child health indicators have been defined as 
infant and under-five mortality rate, rate of under-one child vaccinated for measles, maternal mortality rate, rate of births by trained attendant, rate of contraceptive use, adolescent pregnancy rate, prenatal care coverage and unsatisfying demand for family planning (Türkiye Binyıl Kalkınma Hedefleri Raporu, 2010). Indicators such as fertility rate, crude birth rate, adolescent pregnancy rate, anemia rate in pregnant women and children, early breastfeeding rate, low weight child rate, measles and tuberculosis immunization rate, induced abortion rate, total abortion rate, and poverty level are defined as other maternal and child health indicators (Bozkurt and Erdim, 2019; Melo et al., 2013; Taşkın, 2020; Törüner and Büyükgönenç, 2012). Below are the data on the main mother and child health indicators in Northern Cyprus.

\section{Mother and Infant Mortality Rate}

The maternal mortality rate is estimated to be 295 per 100,000 live births worldwide for 2017 and is more common in underdeveloped countries (WHO, 2017). According to the State Planning Organization (SPO) data, women's life expectancy at birth is 84.5 years. No data was available on the maternal mortality rate. One of the important indicators demonstrating health, development, and child health levels in countries is the infant mortality rate (Bozkurt and Erdim, 2019). According to the World Health Organization data, the infant mortality rate is 51 per 1000 live births in African regions whereas this ratio is 8 per 1000 in European regions (WHO, 2017). The infant mortality rate has been determined to be 0.8 per 1000 live births in Northern Cyprus (SPO, 2017). According to the current SPO data, no stillbirth was reported between 2013 and 2017 (SPO, 2017). The infant mortality rate in the country was found to be lower than that of underdeveloped and developing countries.

\section{Total Fertility Rate}

The fertility rate is approximately 2.4 per woman worldwide. In underdeveloped countries, this number exceeds 5 on average (World Population Review, 2020). According to the SPO data, in 2011, the crude birth rate was 14.6 per thousand and the fertility rate was 1.8 
in the country (KKTC Devlet Planlama Örgütü, 2017). The fertility rate was found to be lower compared to underdeveloped and developing countries (World Population Review, 2020).

\section{Skilled Birth Attendant and Cesarean Rate}

It has been reported that a total of 25 midwives had been working in state hospitals for 2011 (KKTC Devlet Planlama Örgütü, 2017). According to the law of the Cyprus Turkish Nurses and Midwives Association, midwives who do not have a bachelor's degree are not allowed to perform their profession in the country. Therefore, according to this law, it is clear that midwives who do not have a bachelor's degree cannot participate in childbirths.

The cesarean rate is $16.0 \%$ worldwide and the World Health Organization recommends that the cesarean rates should not exceed $15 \%$ (WHO, 2014). Although there is no national data on cesarean rates in Northern Cyprus, according to Northern Cyprus Ministry of Health data, the cesarean rate of the most comprehensive state hospital was 47.6\% in 2017 (KKTC Sağlık Bakanlığı, 2017). In the study conducted by Sarpkaya Güder et al., it was found that the cesarean rate in a private hospital was $87 \%$ for the control group who did not receive a preparatory birth training (Sarpkaya Güder et al., 2018). In the study conducted by Duran, the cesarean rate in a private hospital was found to be $65 \%$ (Duran, 2018).

\section{Use of Family Planning Method}

Worldwide, $12 \%$ of married women aged 15-49 do not use an effective contraceptive method even when they want to prevent pregnancy (WHO, 2019). The frequency of using modern methods in the world has been determined to be $57.4 \%$ (WHO, 2019). There are no national data on the use of family planning methods in Northern Cyprus. In a study conducted in Iskele Region of the country (among 334 women), it was determined that the first four methods still used by women aged 15-49 years were interruptus, tubal ligation, intrauterine device, and condom respectively (Sarpkaya and Eroğlu, 2011). In the same study, it was found that $83.5 \%$ of the women used one method and $44.0 \%$ used a modern method (Sarpkaya and 
Eroğlu, 2011). There are no family planning clinics in private and public hospitals and health centers and family planning services are not provided sufficiently (Sarpkaya and Eroğlu, 2011).

\section{Total Abortion and Induced Abortion Rate}

Between 2010 and 2014, 27 out of 1000 women in developed countries and 36 out of 1000 women in developing countries had undergone curettage (Singh et al., 2018). There is no national data on spontaneous or induced abortion rates in the country. According to a study conducted in Iskele Region (among 334 women), 25.4\% of the women had a spontaneous abortion and 27.5\% had a curettage before (Sarpkaya and Eroğlu, 2011).

Termination of pregnancy is regulated by article 169 of the Penal Code. With this law, the termination of pregnancy is allowed only in the first ten weeks of pregnancy. The procedure should be performed by a registered obstetrician and gynecologist without situations specified in the law (Paşa, 2012). Although curettage is included in the law, illegal curettage cases are encountered in Northern Cyprus as a result of uncontrolled curettage cases (Asit, 2019; Saygun, 2017). In the study conducted by Asit (2019), it was found that there were 115 reports in which there were many ethical violations until the trial on the "illegal curettage" case submitted to the judiciary in Northern Cyprus Media was concluded (Asit, 2019).

\section{Rate of Exclusive Breastfeeding for Six Months}

There is no national data available in the country on exclusive breastfeeding for 6 months. When the relevant studies were examined, in a study conducted in the most comprehensive training and research hospital in Northern Cyprus, it was found that the rate of exclusive breastfeeding for 6 months was $41.7 \%$ (Duran, 2018). In a different study conducted in the most comprehensive public hospital, it was found that the rate of exclusive breastfeeding for 6 months was 22.4\% among working mothers (Özlüses, 2014). In a study conducted with 187 mothers in a private hospital in the Famagusta region, it was found that the mean duration of exclusive breastfeeding was $3.29 \pm 0.17$ months and that the mean duration of breastfeeding 
was $8.10 \pm 0.57$ months (Şafak and Ata Tutkun, 2015). The World Health Organization recommends exclusive breastfeeding for the first 6 months even without giving water to the infant. According to the results of the research conducted in Northern Cyprus, it is seen that the rate of exclusive breastfeeding for 6 months is very low.

\section{Prenatal Follow-up, Postpartum Care, Maternal and Child Health Service}

The World Health Organization recommends at least 4 follow-ups for the prenatal period, including training and counseling services during pregnancy. It is also emphasized that postpartum care should be given within two days after birth (WHO, 2012). In Northern Cyprus, prenatal follow-ups are conducted every day between 9 a.m. and 12 a.m. in public hospitals and health centers and mostly, private hospitals and clinics are preferred for follow-ups. There is no data available on the frequency and scope of prenatal and postnatal follow-ups.

In health centers, basic practices such as pregnant and infant follow-ups and vaccination are provided only if the citizen applies to the relevant health institution and no regular recording is made. In addition, there are no special units regarding maternal and child health neither in health centers nor in the organization of the ministry. Furthermore, there is no family medicine practice system. Currently, the insufficient number of practitioners working in Northern Cyprus is another problem regarding human resources in the system and this can make it difficult to provide better primary care services by improving health centers. The absence of midwives in Northern Cyprus health centers is also considered to be an important inadequacy in terms of maternal and child health services (KKTC-FOKUS, 2020).

A national vaccination program, which was conducted by the Ministry of Health and the Cyprus Turkish Pediatric Association, is implemented in health centers. Vaccines administered free of charge in this program include hepatitis B, DaBT-IPV-HIB, DaBT-IPV, dt (dbt), OPV, Pneumococcus, chickenpox, MMR, and hepatitis A. There are no studies in the country on immunization. According to the Northern Cyprus Ministry of Health Statistics 
Reports, the most reported diseases between 2014 and 2018, which are obliged to be reported, were HIV (+) (66 cases), lung tuberculosis (53 cases), hepatitis B (50 cases), measles (44 cases) and chickenpox (40 cases) (Sağlık Bakanlığı, 2017). Considering the common diseases in the country, the information gap on the immunization status of children at the national level is thought to be important.

\section{CONCLUSION}

The health of a society can be ensured by protecting children from all kinds of damages starting from the prenatal period until adulthood, and providing a qualified childbirth service and postnatal protective and supportive services to the mothers (Bozkurt and Erdim, 2019). It is concluded that many criteria regarding maternal and child health in Northern Cyprus are not presented at the national level and that there are no sufficient scientific studies on the subject. Primary data such as maternal mortality rate, newborn mortality rate, under-five mortality rate, immunization status in children, adolescent pregnancy rate, frequency and coverage of prenatal and postnatal care was not available. Relevant scientific studies are recommended since data such as unsatisfied demand for family planning, breastfeeding rate, infant immunization status, cesarean delivery rate, total abortion rate, and induced abortion rate has not been presented at the national level.

In terms of monitoring and evaluating health programs and determining future policies, it is of great importance to estimate the levels, trends, and differences in maternal mortality rate and in neonatal, postnatal and child mortality. According to current data, the rate of exclusive breastfeeding for the first 6 months is low; the cesarean rate is high; there is a lack of services regarding maternal and child health. It can be said that the risk of HIV transmission is high in terms of maternal and infant health due to the high number of HIV (+) cases in the country. The infant mortality rate and fertility rate were found to be low compared to underdeveloped and developing countries. 
Ethical Approval: Ethics committee approval has not been obtained since this study was not conducted on either humans or animals. The review research used documentary analysis method.

Authors' Contributions: Sections of the study were written by a single author.

Funding and Acknowledgment: This research did not receive any specific funding.

Conflict of Interest Statement: The author declares no conflicts of interest.

\section{REFERENCES}

Asit, G. (2019). Kuzey Kıbrıs Türk Cumhuriyeti medyasında etik sorunsalı: Kürtaj davası haberleri örneği Gümüşhane Üniversitesi İletişim Fakültesi Elektronik Dergisi, 7,321-344.

Bozkurt, G., Erdim, L. (2019). Türkiye'de anne çocuk sağllğı durumu. Sağlık Bilimleri ve Meslekleri Dergisi, 6,575-582.

Duran, S. (2018). Determination of mothers feeding their babies with breast milk in the first 6 months. Near East University, Institute of Health Sciences, Northern Cyprus.

KKTC Devlet Planlama Örgütü. (2018, July 16). Ekonomik ve sosyal göstergeler 2011-2016. http://www.devplan.org/frame-tr.Html

KKTC Devletinde Fonksiyonel ve Kurumsal Gözden Geçirme Projesi (KKTC-FOKUS). (2019, February 1). Kurumsal ve fonksiyonel analiz çalışması 2012. https://www.tepav.org.tr/upload/files/1455007392-

KKTC Sağlık Bakanlığı. (2019, August 23). 2017 sağlık istatistikleri. http://www.saglikbakanligi.com/

Melo, E.C., Ribeiro, A.B.G., De Oliveira, R.R., Zurita, R.C.M., De Freitas Mathias, T.A. (2013). Analysis of maternal and child health indicators in an area at Paraná State, Brazil. Nursing Research and Practice. 495178,19.

Özlüses, E. (2014). The Effect of natural feeding instruction given to parents on the duration of breastfeeding alone, growth parameters of babies, sickness rates and parent-infant attachment. Near East University, Institute of Health Sciences, Northern Cyprus.

Paşa, F.D. (2012). Kuzey Kıbrıs’ta kadının insan hakları. Lefkoşa: Kıbrıslı Türk İnsan Hakları Vakfı Yayınları.

Sarpkaya Güder, D., Yalvaç, M., Vural, G. (2018). The effect of pregnancy Pilates-assisted childbirth preparation training on childbirth fear and neonatal outcomes: A quasi-experimental/quantitative research. Quality and Quantity, 52,2667-79.

Sarpkaya, D., Eroğlu, K. (2011). Kuzey Kıbrıs Türk Cumhuriyeti'nde 15-49 yaş grubu kadınların aile planlaması yöntemi kullanımı ve etkileyen faktörler. Türkiye Klinikleri Tıp Bilimleri Dergisi, 31,1236-1244.

Saygun, Ö. (2019, July 14). Kuzey Kıbrıs'ta kürtaj. https://kaosgl.org/haber/kuzey-kibris-kadinin-kurtaj-hakkinitanimiyor

Singh, S., Remez, L., Sedgh, G., Kwok, L., Onda, T. (2020, January 10). Abortion Worldwide 2017: Uneven progress and unequal access. https://www.guttmacher.org/sites/default/files/report_pdf/abortion-worldwide2017.pdf

Şafak, Ç., Ata Tutkun, N. (2015). Anne sütü ile beslenme sürelerinin yaşam çözümlemesi ile incelenmesi: Kuzey Kıbrıs Türk Cumhuriyeti örneği. İzmir Dr. Behçet Uz Çocuk Hast. Dergisi, 5,167-176. 
Taşkın, L. (2020). Doğum ve kadın sağlığı hemşireliği. Ankara: Akademisyen Kitabevi.

Törüner, E.K., Büyükgönenç, L. (2012). Çocuk sağlığı: Temel hemşirelik yaklaşımları. Ankara: Göktuğ Yayıncilık.

Türkiye Binyı Kalkınma Hedefleri Raporu. (2019, $\quad$ August 10$)$. https://www.tr.undp.org/content/turkey/tr/home/library/mdg/mdgreportTurkey2010.html

World Health Organization (WHO) (2020, January 10). Births by caesarean section, 2014. http://apps.who.int/iris/bitstream/10665/112738/1/9789240692671_eng.pdf,

World Health Organization (WHO) (2020, January 10). Family planning/contraception methods. https://www.who.int/news-room/fact-sheets/detail/family-planning-contraception

World Health Organization (WHO) (2020, January 10). Maternal, newborn, child and adolescent health, 20002017. https://www.who.int/gho/maternal_health/countries/gtm.pdf?ua=1

World Population Review (2020, January 10). Total fertility rate 2020, http://worldpopulationreview.com/countries/total-fertility-rate/ 